\title{
Obat Anti Malaria
}

\author{
Emil Azlin
}

Malaria adalah penyakit infeksi parasit pada manusia dan masih menjadi masalah kesehatan masyarakat. Penggunaan obat anti malaria merupakan upaya penting dalam pemberantasan malaria. Kegagalan pengobatan disebabkan ketidaktepatan regimen dan dosis obat yang diberikan, resistensi dari Plasmodium terhadap obat, serta belum adanya obat anti malaria yang ideal. Penelitian mengenai obat anti malaria terus berkembang seiring dengan peningkatan resistensi dari Plasmodium yang berbeda di tiap daerah. Saat ini obat anti malaria yang tersedia di Indonesia adalah klorokuin, sulfadoksin-pirimetamin, kina, primakuin, dan artemeter.

Kata kunci: anti malaria, klorokuin, sulfadoksin-pirimetamin, kina, primakuin, artemeter.

$\mathcal{M}$ alaria merupakan salah satu penyakit menular yang re-emerging, karena $\pm 35 \%$ penduduk Indonesia tinggal di daerah endemis malaria. Menurut survai kesehatan rumah tangga (SKRT) tahun 1995 diperkirakan setiap tahunnya terdapat 15 juta kasus malaria dan 30.000 orang di antaranya meninggal dunia. Sejak empat tahun terakhir angka kesakitan malaria menunjukkan kecenderungan yang mengkhawatirkan. Peningkatan kasus diakibatkan adanya perubahan lingkungan, mobilitas penduduk, dan meningkatnya resistensi terhadap obat anti malaria. ${ }^{1}$

Menurunnya sensitifitas dapat timbul akibat pengobatan yang terus menerus dan tidak adekuat, sehingga terjadi mutasi parasit, di samping itu juga diduga dibawa dari daerah yang resisten. ${ }^{2}$ Dalam tiga puluh tahun terakhir, P. falciparum telah resisten terhadap obat anti malaria yang ada. Resistensi klorokuin juga sudah terjadi terhadap P. vivax dan telah dilaporkan dari Papua New Guinea, India, Myanmar, dan Indonesia. Akibatnya pengobatan malaria harus disesuaikan dengan kondisi geografis tiap negara. ${ }^{3}$

Alamat Korespondensi:

Dr. Emil Azlin.

Bagian Ilmu Kesehatan Anak. FK-USU/RS H Adam Malik, Medan. Jl. Bunga Lau no. 17, Medan 20136.

Telepon: 061-836 1721. Fax. 061-836 1721.
Tujuan tulisan ini adalah untuk membahas beberapa obat anti malaria yang dipakai di Indonesia sesuai dengan rujukan dari perkembangan obat anti malaria saat ini.

\section{Klasifikasi}

Obat anti malaria dapat dibagi berdasarkan aktifitas obat pada stadium parasit sebagai berikut ${ }^{4-6}$

1. Skizontosida jaringan untuk profilaksis kausal bekerja pada awal siklus eritrositik setelah berkembang di hati. Primakuin dan pirimetamin merupakan obat jenis ini. Namun sangat sulit untuk menduga infeksi malaria sebelum dijumpainya gejala klinis sehingga pengobatan tipe ini lebih bersifat teori dari pada praktek.

2. Skizontisida jaringan untuk mencegah relaps bekerja pada bentuk hipnozoit dari P. vivax dan P. ovale di hati dan digunakan untuk pengobatan radikal sebagai obat anti relaps. Obat utama yang termasuk dalam kelompok ini adalah primakuin, tetapi pirimetamin juga mempunyai aktifitas serupa.

3. Skizontosida darah

membunuh parasit pada siklus eritrositik, yang berhubungan dengan penyakit akut disertai gejala klinis. Obatnya adalah kuinin, klorokuin, meflokuin, halofantrin, sulfadoksin, dan pirimetamin yang mempunyai efek terbatas. 
4. Gametositosida

bekerja dengan menghancurkan bentuk seksual semua spesies Plasmodium malaria di darah sehingga mencegah transmisi parasit ke tubuh nyamuk. Obatnya adalah primakuin untuk keempat spesies Plasmodium serta klorokuin dan kuinin untuk P. vivax, P.malariae, dan P. ovale.

5. Sporontosida

bekerja dengan menghambat perkembangan ookista dalam tubuh nyamuk sehingga mencegah terjadinya transmisi lebih lanjut. Obat golongan ini adalah primakuin dan kloroguanid.

Dari sekian banyak jenis obat anti malaria, yang tersedia di Indonesia hanyalah klorokuin, sulfadoksinpirimetamin, kina, primakuin, dan artemeter. Departemen Kesehatan mempunyai kebijakan untuk dapat memantau obat yang tepat dan benar. Hal ini berdasarkan pada obat anti malaria yang tersedia, jenis dan beratnya malaria, resistensi daerah tersebut, serta fasilitas laboratorium. Kebijaksanaan ini bertujuan untuk menghambat timbulnya resistensi terhadap obat anti malaria yang disebabkan kesalahan penggunaan obat. ${ }^{7}$

\section{Klorokuin}

Klorokuin merupakan obat anti malaria kelompok 4amionokuinolin, merupakan anti malaria utama dan paling banyak digunakan dalam pengobatan malaria, harga murah dan terbukti aman. ${ }^{4}$ Di Indonesia klorokuin mulai dipakai pada tahun 1946. Kasus P. falciparum yang resisten terhadap klorokuin pertama kali dilaporkan pada tahun 1974 dari Kalimantan Timur, hingga tahun 1992 resistensi sudah dilaporkan dari seluruh wilayah Indonesia. ${ }^{6,7}$

Mekanisme kerja obat ini belum jelas, karena bersifat alkalis obat ini dapat mencapai konsentrasi yang tinggi dalam vakuola makanan dari parasit dan meningkatkan pH-nya. Klorokuin menekan enzim heme-polimerase dari parasit yang berfungsi mengubah heme toksin menjadi hemozoin non-toksik yang dihasilkan dari penumpukan heme toksik di dalam tubuh parasit. Klorokuin juga menghambat proses biosintesis asamnukleat. ${ }^{4,8}$

Klorokuin 90\% diserap di dalam saluran cerna dan secara cepat diabsorbsi pada pemberian intra muskular dan subkutan. Obat ini mempunyai volume distribusi yang luas karena pemisahan yang besar di hati, limpa, ginjal, paru, sehingga pada pemberian awal diperlukan dosis yang besar. Kadar terapi di darah menetap selama
6-10 hari dengan waktu paruh 1-2 minggu. Setengah dari obat diekskresi utuh oleh ginjal, sisanya diubah menjadi metabolit aktif di hati. .,6 $^{4}$

Obat ini sangat efektif terhadap bentuk eritrosit dari $P$. vivax, $P$. ovale, $P$. malariae, dan $P$. falciparum serta gametosit $P$. vivax dan $P$. malariae. Secara cepat mengontrol serangan akut malaria dan menjadikan pasien tidak demam lagi dalam waktu 24-48 jam. Obat ini lebih efektif dan aman dibandingkan kina pada kasus yang sensitif. ${ }^{4,8}$ Mekanisme terjadinya resistensi obat, berhubungan dengan kemampuan parasit untuk menghalangi konsentrasi klorokuin yang tinggi di vakuola makanan parasit, sehingga penekanan enzim hemepolimerase tidak terjadi. ${ }^{6,9}$ Angka kesembuhan sangat bervariasi antara $10-100 \%$ dengan derajat resistensi antara R I - R III. ${ }^{10}$

Efek samping yang ditemukan biasanya ringan seperti pusing, vertigo, diplopia, mual, muntah, dan nyeri perut. Walaupun demikian pada dosis profilaksis 300 $\mathrm{mg}$ basa/minggu, dapat menyebabkan toksik pada retina setelah pemakaian 3-6 tahun. Pemberian intra muskular dapat menyebabkan hipotensi dan henti jantung, terutama pada anak. Klorokuin harus diberikan hati-hati pada pasien penyakit hati, saluran cerna berat, gangguan neurologi, dan penyakit darah. ${ }^{4,8}$

Klorokuin tersedia sebagai tablet klorokuin fosfat 250 mg yang mengandung $150 \mathrm{mg}$ basa. Klorokuin dihidroklorida injeksi mengandung $40 \mathrm{mg}$ basa tiap ml. Dosis oral diberikan pada hari pertama dengan dosis $10 \mathrm{mg} / \mathrm{kg}$ berat badan, diikuti 6 jam kemudian dengan dosis $5 \mathrm{mg} / \mathrm{kg}$, serta pada hari kedua dan ketiga dengan dosis $5 \mathrm{mg} / \mathrm{kg}$. Pemberian secara intra vena dengan dosis $10 \mathrm{mg} / \mathrm{kg}$ berat badan selama $\geq 8$ jam, dilanjutkan 15 $\mathrm{mg} / \mathrm{kg}$ selama $\geq 24$ jam (pemberian dalam $10 \mathrm{ml} \mathrm{NaCl}$ $0,9 \%$ /dekstrosa $5 \%)^{4,6}$

\section{Kuinin / Kina}

Kuinin adalah alkaloid utama dari kulit pohon kina, sejenis pohon yang ditemukan di Amerika Selatan. Calancha, seorang Rahib dari Lima Peru pertama kali menulis kegunaan pengobatan dengan tepung kina pada demam yang berulang pada awal tahun 1633. Pada tahun 1820, Pelletier dan Caventou memisahkan kinin dan kinkonin dari cinchona. Hingga sekarang kina diperoleh secara utuh dari sumber alam disebabkan sulitnya mensintesa kompleks molekulnya. ${ }^{4}$

Kina bekerja sebagai skizontosida darah dan gametositosida terhadap $P$. vivax dan $P$. malariae. 
Karena kina merupakan suatu basa lemah, konsentrasinya tinggi di vakuola makanan pada $P$. falciparum. Obat ini bekerja dengan menghambat hemepolimerase, sehingga mengakibatkan penumpukan zat sitotoksik yaitu heme. Sebagai skizontosida, kina kurang efektif dan lebih toksik dibanding klorokuin, tetapi kina mempunyai tempat tersendiri dalam penanganan malaria berat di daerah P. falciparum resisten terhadap klorokuin. ${ }^{4,6}$

Kuinin mudah diabsorbsi pada pemberian secara oral atau intra muskular. Kadar puncak dalam plasma dicapai 1-3 jam setelah pemberian oral dan waktu paruh sekitar 11 jam. Pada malaria akut volume distribusi kuinin yang berikatan dan klirensnya menurun, serta waktu paruhnya meningkat sejalan dengan keparahan penyakit. Dosis pemeliharaan harus diturunkan bila pengobatan lebih dari 48 jam. Obat ini dimetabolisme di hati dan hanya $10 \%$ diekskresi secara utuh di urin. Tidak dijumpai penumpukan efek toksik pada pemberian yang lama. ${ }^{4}$

Kuinin berpotensi toksik; tipe dari gejala efek samping kuinin disebut cinchonism dan biasanya ringan pada dosis terapi namun bisa berat pada dosis yang lebih besar. Penurunan fungsi nervus VIII dan gangguan penglihatan bisa dijumpai. Kuinin menstimulasi sekresi insulin dan dapat menyebabkan hipoglikemia yang tidak terdeteksi sehingga dapat menyebabkan kematian. Dianjurkan untuk memonitor kadar gula darah dalam 4-6 jam setelah pemberian kuinin. Keadaan hipoglikemia ini dapat berulang walaupun pasien telah diberikan dekstrosa $25 \%$ atau $50 \%$, sehingga pencegahan dengan infus dekstrosa $10 \%$ sangat dianjurkan. Hipoglikemia yang resisten akibat pemberian kuinin dapat diatasi dengan pemberian injeksi octreotide $50 \mu \mathrm{g} /$ subkutan setiap 6-8 jam. ${ }^{4,6}$

Hipersensitifitas pada pasien yang mengalami ruam, angioedem, gangguan pendengaran dan penglihatan merupakan indikasi untuk menghentikan pengobatan. Obat ini dikontraindikasikan pada kasus dengan tinitus dan neuritis optikus. Pemberian pada pasien dengan fibrilasi atrial harus hati-hati. Perdarahan merupakan indikasi relatif untuk menghentikan pengobatan. Obat ini tidak boleh diberikan pada pasien myasthenia gravis. ${ }^{4}$

Kuinin tersedia dalam bentuk tablet dan kapsul berisi 300 dan $600 \mathrm{mg}$ basa. Juga tersedia dalam bentuk injeksi mengandung $300 \mathrm{mg} / \mathrm{ml}$. Dosis oral adalah 10 $\mathrm{mg} / \mathrm{kg}$ berat badan $/ 8$ jam selama 4 hari pertama dan dilanjutkan $15 \mathrm{mg} / \mathrm{kg}$ berat badan $/ 8$ jam selama 4 hari kedua.
Intra vena $20 \mathrm{mg} / \mathrm{kg}$ berat badan dalam > 4 jam dan dilanjutkan $10 \mathrm{mg} / \mathrm{kg}$ dalam $>4$ jam (pemberian dalam $\mathrm{NaCl}$ 0,9\%/Dekstrosa 5\%) diberikan setiap 8 jam sehingga pasien dapat minum obat atau selama 5-7 hari. ${ }^{4,6}$

\section{Primakuin}

Primakuin adalah anti malaria esensial yang dikombinasikan dengan klorokuin dalam pengobatan malaria. Obat ini efektif terhadap gametosid dari semua Plasmodium sehingga dapat mencegah penyebaran penyakit. Juga efektif terhadap bentuk hipnozoit dari malaria vivax dan $\mathrm{m}$. ovale sehingga dapat digunakan untuk pengobatan radikal dan mencegah relaps. Obat ini tidak mempunyai efek yang nyata terhadap bentuk aseksual parasit di darah sehingga selalu digunakan bersamaan dengan skizontosida darah dan tidak pernah digunakan sebagai obat tunggal. ${ }^{4,6}$

Mekanisme kerja obat ini belum jelas, diduga obat ini bekerja dengan menghasilkan oksigen reaktif atau berkompetisi dengan transport elektron dalam tubuh parasit. Primakuin diabsorbsi dengan baik setelah pemberian oral dan dengan cepat dimetabolisasi. Waktu paruh \pm 6 jam. Metabolit dari primakuin merupakan bahan oksidatif dan dapat menyebabkan hemolisis pada pasien yang sensitif., ${ }^{4,6}$

Primakuin ditoreransi dengan baik, namun pada dosis besar dapat menyebabkan nyeri epigastrium dan kaku perut. Keadaan ini dapat dikurangi dengan memberikannya bersamaan dengan makanan. Pasien dengan defisiensi G6PD akan berkembang menjadi anemia hemolitik pada pemberian dosis biasa. Obat ini harus dihentikan bila dijumpai tanda-tanda hemolisis dan anemia. Primakuin tidak boleh digunakan pada pasien dengan penyakit sistemik berat dan tidak boleh diberikan bersamaan kuinin, meflokuin, atau obat yang dapat menekan sumsum tulang. ${ }^{4,6}$

Primakuin tersedia dalam bentuk tablet berisi 15 mg bentuk basa. Diberikan setelah pemberian klorokuin dengan dosis $0.25 \mathrm{mg} / \mathrm{kg}$ berat badan $/$ hari selama 5 hari untuk infeksi P. vivax dan P. ovale serta $0.75 \mathrm{mg} / \mathrm{kg}$ berat badan dosis tunggal pada infeksi $\mathrm{P}$ falciparum. ${ }^{4,8}$

\section{Sulfadoksin-Pirimetamin}

Sulfadoksin-pirimetamin merupakan obat anti malaria kombinasi sulfonamida/sulfon dan diaminopirimidin. Obat ini bersifat skizontosid jaringan terhadap 
P.falciparum dan skizontosida darah serta sporontosida untuk keempat jenis Plasmodium. ${ }^{4}$ Obat ini digunakan secara selektif untuk pengobatan radikal malaria falsiparum yang resisten terhadap klorokuin. ${ }^{10}$

Sulfadoksin-pirimetamin disebut juga kelompok obat anti folat karena bekerja dengan menghalangi dua jalur pembentukan folat pada tubuh parasit. Sulfadoksin menghalangi penggunaan para-aminobenzoic acid (PABA) dengan menghambat enzim dihydropteroate synthase (DHPS). Pirimetamin menghambat enzim dihydrofolat reductase (DHFR) dari Plasmodium sehingga menghalangi sintesa timin dan purin yang merupakan bahan penting untuk sintesa DNA dan multiplikasi sel., ${ }^{4,6}$ Mekanisme terjadinya resistensi pada kombinasi obat ini disebabkan mutasi gen spesifik parasit. ${ }^{6,8-9}$

Pirimetamin secara lambat tetapi utuh diabsorbsi setelah pemberian oral dan dieliminasi dengan lambat. Waktu paruhnya 80 - 95 jam. Konsentrasi yang efektif bisa dijumpai dalam plasma selama lebih dari 2 minggu. Obat ini bisa diekskresikan melalui ASI. Sulfadoksin secara cepat diabsorbsi dari usus dan berikatan dengan plasma protein dan kemudian dimetabolisasi di hati dan diekskresikan melalui urin. Obat ini dapat melewati plasenta secara bebas dan merupakan sulfonamid jangka panjang dengan waktu paruh berkisar 7 - 9 hari. ${ }^{4,6}$

Pirimetamin dapat menyebabkan ruam dan menekan hematopoesis. Dosis yang berlebihan dapat menimbulkan anemia megaloblastik. Sulfonamid dapat menimbulkan banyak efek samping seperti agranulositosis, aplastik anemia, reaksi hipersensitifitas, sindrom Steven Johnson, dermatitis eksfoliatifa, serum sickness, gangguan fungsi hati, anoreksia, muntah, dan anemia hemolitik. Obat ini tidak boleh di berikan pada pasien yang hipersensitif terhadap sulfa, bayi di bawah usia 2 bulan, pasien gagal ginjal kronik, dan pada wanita hamil. ${ }^{4,6}$

Sulfadoksin-pirimetamin tersedia dalam bentuk tablet berisi $25 \mathrm{mg}$ pirimetamin dan $500 \mathrm{mg}$ sulfadoksin setiap tablet. Dosis yang diberikan untuk pengobatan malaria falsiparum adalah untuk sulfadoksin $25 \mathrm{mg} / \mathrm{kg}$ berat badan dan pirimetamin $1,25 / \mathrm{kg}$ berat badan dosis tunggal. Angka kesembuhan yang dilaporkan antara $92-100 \%$ dengan derajat resistensi R I - R II. ${ }^{10}$

\section{Derivat Artemisin}

Artemisin atau qinghaosu adalah bahan aktif utama dari obat tradisional Cina yang bernama artemisia annua. Obat ini sudah digunakan untuk pengobatan malaria di Cina selama lebih dari 1000 tahun. Manfaat artemisia annua pertama kali ditulis dalam Zhou Hou Bei Ji Fang yang ditulis pertama kali pada tahun 340 AD oleh Ge Hong pada masa dinasti Jin. Bahan aktif dari tanaman ini di isolasi pada tahun 1971 dan dinamakan artemisin. Badan Kesehatan Dunia sangat mendukung pengembangan derivat artemisin yang bereaksi cepat dalam pengobatan malaria serebral dan untuk mengontrol malaria falsiparum yang resisten terhadap berbagai obat. ${ }^{4}$

Aktifitas anti malaria dari bahan aktif obat ini berada pada struktur endoperoksida yang unik. Besi dari pemecahan hemoglobin mereduksi ikatan endoperoksid dan melepaskan dengan kuat radikal bebas besi oxo dari spesies yang dapat membunuh parasit. Artemisin juga memperlambat sintesa protein dalam perkembangan parasit dan bekerja pada membran parasit dengan memakai oksigen lipid dengan peroksidasi lemak. Obat ini menghambat perkembangan tropozoit yang berarti mencegah progresivitas penyakit. ${ }^{4,11}$

Derivat artemisin diabsorbsi dengan baik pada pemberian secara intra muskular maupun oral, dimetabolisme seluruhnya dan metabolit yang terbesar adalah dihidroartemisinin yang juga memiliki efek anti parasit. Obat ini dapat mulai bekerja 12 jam setelah pemberian dan dibersihkan secara cepat yang sebagian besar melalui aliran empedu. ${ }^{4,11}$

Artemisin relatif aman, pada beberapa penelitian belum dijumpai adanya efek teratogenik pada embrio dari binatang percobaan. ${ }^{4}$ Penelitian terhadap manusia sudah banyak dilakukan di Thailand terhadap pasien malaria falsiparum yang resisten terhadap berbagai obat dengan obat tunggal maupun dikombinasi dengan meflokuin. Dari beberapa penelitian tersebut didapatkan hasil pengobatan yang baik dan aman. ${ }^{12-14}$ Penelitian pengobatan malaria falsiparum yang resisten terhadap berbagai obat artemether oral juga sudah pernah dilakukan di Kalimantan Timur dan Papua. Hasil penelitian tersebut juga menunjukkan adanya efikasi yang baik dan aman. ${ }^{15-16}$

Artemisin tersedia dalam bentuk derivatnya yaitu artemether, artesunat, dan arteether. Artemether tersedia dalam bentuk injeksi berisi $80 \mathrm{mg}$ dalam $1 \mathrm{ml} .{ }^{17}$ Tablet artemeter yang berisi $50 \mathrm{mg}$ tiap tabletnya sekarang sudah tersedia di Indonesia. Artemeter diberikan dengan dosis awal 3,2 mg/kg berat badan/hari, dilanjutkan 1,6 $\mathrm{mg} / \mathrm{kg} /$ hari hingga pemberian oral dapat dilaksanakan atau maksimal 7 hari. Pengobatan secara oral diberikan 
dengan dosis $4 \mathrm{mg} / \mathrm{kg}$ berat badan pada hari pertama dalam dua kali pemberian, dan dilanjutkan dengan 2 $\mathrm{mg} / \mathrm{kg}$ berat badan/hari selama $5-7$ hari. ${ }^{18-19}$

\section{Ringkasan}

Malaria masih merupakan masalah bagi kesehatan masyarakat karena angka kesakitan dan kematian yang ditimbulkannya masih tinggi. Obat anti malaria berkembang sesuai kebutuhan daerah geografis malaria dan penggunaan obat anti malaria harus berdasarkan pada kebutuhan daerah tersebut. Penggunaan obat anti malaria baru perlu dibatasi, diperuntukkan hanya pada kasus yang gagal dengan obat standar. Untuk mendapatkan obat anti malaria yang mendekati ideal dan untuk memperlambat terjadinya galur P.falciparum resisten terhadap obat dianjurkan menggunakan kombinasi obat yang sesuai.

\section{Daftar Pustaka}

1. Departemen Kesehatan Republik Indonesia. Profil Kesehatan Indonesia 2000. Jakarta: Departemen Kesehatan RI; 2001. h. 37-46.

2. Santoso SS, Rukmono B, Pribadi W, Soesanto SS, Sudarti. Pengetahuan, pengalaman, Pandangan, dan Pola Pencarian Pengobatan tentang Penyakit Malaria di Daerah Hiperendemik Mimika Timur Irian Jaya. Buletin Penelit. Kesehat. 1994; 22:24-38.

3. Luxemburger C. Treatment of Malaria in Young Children. J Pediatr Obstet Gynecol 1999; 5-9.

4. Kakkilaya BS. Antimalarial drugs. Dr.B.S. Kakkilaya's Malaria Web Site. Didapat dari: URL: http:// www.geocities.com/HotSprings/Resort/5403/Antimalarial

5. Pribadi W, Sungkar S. Malaria. Balai Penerbit Fakultas Kedokteran Universitas Indonesia Jakarta, 1994. h. 1524.

6. Tracy JW, Webster LT. Drugs Used in Chemotherapy of Protozoa Infections. Dalam: Hardman JG, Gilman AG, Limbird LE. Penyunting. Goodman \& Gilman's The
Pharmacological Basis of Therapheutics. Edisi ke-9. New York: Mc Milan, 1996. h. 965-85.

7. Tjitra E. Pengobatan Malaria. Maj. Kedok. Indon. 1996; 24-32.

8. Departemen Kesehatan Republik Indonesia. Malaria : Pengobatan. Jakarta: Direktorat Jenderal PPM \& PLP; 1995.

9. World Health Organization. Drug Resistance In Malaria. WHO/CDS/CSR/DRS/2001.4.

10. Tjitra E. Obat-obat baru anti malaria. Cermin Dunia Kedok. 1994; 94:16-22.

11. Taylor TE, Strickland GT. Malaria. Dalam: Strickland GT, penyunting. Hunter's Tropical Medicine and Emerging Infectious Diseases. Philadephia: W.B. Saunders; 2000. h. 614-43.

12. Bunnag D, Viravan C, Looareesuwan S, Karbwang J, Harinasuta T. Clinical Trial of Artesunate and Artemether on Multidrug Resistant Falciparum Malaria in Thailand. A Preliminary Report. Southeast As J Trop Med Pub Health 1991; 22:380-5.

13. Bunnag D, Kanda T, Karbwang J, Thimasarn K, Pungpak S, dkk. Two doses of artemether/mefloquine or artesunate/mefloquine combination for multidrug resistant Falciparum malaria. Southeast As J Trop Med Pub Health 1997; 28:727-35.

14. Looareesuwan S, Wilairatana P, Viriyavejakul P, Chokejindachai W, Krudsood S. Research on new antimalarial drugs and the use of drugs in combination at the Bangkok hospital for tropical dDiseases. South As J Trop Med Pub Health 1998; 29: 344-54.

15. Tjitra E, Pribadi W, Raharjo K, Budiono W, Arbani PR, dkk. Treatment of uncomplicated in vitro chloroquine resistant Falciparum malaria with artemether in Irian Jaya. Med J Indones 1996; 5:33-40.

16. Tjitra E. Tinjauan hasil ujicoba pengobatan dan pencegahan malaria di beberapa tempat di Indonesia. Bul. Penelit. Kes. 1997; 25:1-25.

17. Artemisinin and its Derivative-?-Artemether. Didapat dari: URL: http://www.arenco.be/docu3.htm.

18. Guerin P, Nosten F, White NJ. Malaria: an essential R\&D agenda. Drugs for neglected diseases working group, Geneva, Switzerland; September 2001.

19. Tjitra E. Obat anti malaria. Dalam: Harijanto PN, penyunting. Malaria epidemiologi, patogenesis, manifestasi klinis, dan penanganan. Jakarta: ECG, 2000. h. 195-223. 